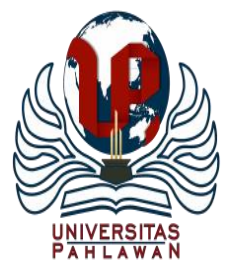

Edukatif : Jurnal Ilmu Pendidikan Volume 3 Nomor 4 Tahun 2021 Halm 1821 - 1829

EDUKATIF: JURNAL ILMU PENDIDIKAN

Research \& Learning in Education

https://edukatif.org/index.php/edukatif/index

\title{
Analisis Kebutuhan Pengembangan Elektronik Modul Berbasis Education For Sustainable Development untuk Siswa di Sekolah Dasar
}

\author{
Nurul Hadi Yanti ${ }^{1 凶}$, Ghullam Hamdu ${ }^{2}$ \\ Universitas Pendidikan Indonesia, Indonesia ${ }^{1,2}$ \\ E-mail : nurulhadi@ upi.edu ${ }^{1}$, ghullamh2012@ @upi.edu ${ }^{2}$
}

\begin{abstract}
Abstrak
Salah satu cara untuk meningkatkan pengembangan kualitas sumber daya manusia dalam dunia pendidikan yaitu dengan melakukan perbaikan dan pengembangan proses maupun perangkat pembelajaran utamanya pada jenjang Sekolah Dasar seperti modul pembelajaran. Penelitian ini bertujuan untuk menganalisis kebutuhan pengembangan elektronik modul berbasis Education for Sustanable Development di kelas V sekolah dasar. Penelitian merupakan penelitian kualitatif menggunakan metode Deskriptif. Subjek penelitian adalah 6 orang guru kelas V dan 7 Orang Siswa kelas V dari empat sekolah yang berada di Kabupaten dan Kota Tasikmalaya. Teknik pengumpulan data menggunakan wawancara dan studi dokumentasi. Analisis data menggunakan teknik dari Miles-Huberman yang terdiri dari reduksi data, penyajian data, dan penarikan kesimpulan. Analisis ini meliputi analisis kurikulum, analisis bahan ajar dan analisis siswa. Penelitian ini menunjukan bahwa bahan ajar yang digunakan saat ini masih belum memenuhi kebutuhan dari peserta didik terlebih saat ini pembelajaran dilaksanakan secara online sehingga peserta didik dan guru membutuhkan bahan ajar tambahan yang mampu menbantu peserta didik untuk belajar mandiri di rumah.
\end{abstract}

Kata Kunci: Analisis kebutuhan, Elektronik modul, Education for Sustainable Development.

\begin{abstract}
One way to improve the development of the quality of human resources in the world of education is to improve and develop processes and learning tools, especially at the elementary school level, such as learning modules. This study aims to analyze the need for the development of electronic modules based on Education for Sustainable Development in fifth grade elementary schools. This research is a qualitative research using descriptive method. The research subjects were 6 fifth grade teachers and 7 fifth grade students from four schools located in the district and city of Tasikmalaya. Data collection techniques using interviews and documentation studies. Data analysis used techniques from Miles-Huberman which consisted of data reduction, data presentation, and drawing conclusions. This analysis includes curriculum analysis, analysis of teaching materials and student analysis. This study shows that the teaching materials used today still do not meet the needs of students, especially when learning is carried out online so that students and teachers need additional teaching materials that are able to help students learn independently at home.
\end{abstract}

Keywords: Needs Analysis, Electronic Module, Education for Sustainable Development.

Copyright (c) 2021 Nurul Hadi Yanti, Ghullam Hamdu

$\square$ Corresponding author

Email: : nurulhadi@upi.edu

DOI : https://doi.org/10.31004/edukatif.v3i4.632

ISSN 2656-8063 (Media Cetak)

ISSN 2656-8071 (Media Online)

Edukatif : Jurnal Ilmu Pendidikan Vol 3 No 4 Tahun 2021 p-ISSN 2656-8063 e-ISSN 2656-8071 
1822 Analisis Kebutuhan Pengembangan Elektronik Modul Berbasis Education For Sustainable Development untuk Siswa di Sekolah Dasar - Nurul Hadi Yanti, Ghullam Hamdu

DOI: https://doi.org/10.31004/edukatif.v3i4.632

\section{PENDAHULUAN}

Pendidikan adalah serangkaian proses belajar untuk mencapai kehidupan yang lebih baik. Pendidikan memegang peranan penting dalam meningkatkan sumber daya manusia di suatu negara. Salah satu cara untuk meningkatkan pengembangan kualitas sumber daya manusia dalam dunia pendidikan yaitu dengan melakukan perbaikan dan pengembangan proses pembelajaran utamanya pada jenjang Sekolah Dasar (Deviana, 2018). Proses pembelajaran dipandang sebagai aspek sangat penting dalam pendidikan. Terdapat beberapa komponen yang mendukung terjadinya proses pembelajaran, diantaranya: peserta didik, pendidik, sumber/bahan ajar, media, metode dan model pembelajaran (Dolong, 2016). Pengembangan salah satu komponen pembelajaran seperti pengembangan bahan ajar dianjurkan untuk dilakukan oleh pendidik supaya pembelajaran menjadi lebih efektif, efisien, dan tidak melenceng dari kompetensi yang akan dicapainya. Salah satu bahan ajar yang dapat digunakan untuk membantu proses pembelajaran adalah modul (BSNP, 2010).

Modul merupakan sebuah buku yang ditulis dengan tujuan supaya siswa dapat belajar secara mandiri tanpa atau dengan bimbingan guru (Majid, 2010). Modul pembelajaran dapat dirancang sesuai dengan kebutuhan pembelajaran yang diinginkan guru. Sejalan dengan hal tersebut, PP No 19 Pasal 20 Tahun 2005 menjelaskan bahwa dalam proses pembelajaran, guru diharapkan mampu mengembangkan bahan atau materi pembelajarannya sendiri sebagai salah satu sumber belajar bagi siswa.

Modul yang akan di jadikan bahan ajar harus relevan dengan kurikulum yang digunakan. Saat ini pendidikan di Indonesia tengah menggunakan kurikulum 2013 dengan pendekatan saintifik dan tematik integratif. Selain itu, dalam Peraturan Menteri Pendidikan Nasional No 63 Tahun 2009 tentang Sistem Penjaminan Mutu Pendidikan (SPMP) Bagian Ketiga menegaskan bahwa pelaksanaan kurikulum 2013 juga di dasarkan pada paradigma Education For Sustainable Development (ESD) untuk mewujudkan masyarakat yang berkelanjutan. ESD dibentuk sebagai upaya untuk memberdayakan individu dari segala tingkat usia untuk turut bertanggungjawab dalam menciptakan sebuah masa depan berkelanjutan (Mochtar et al., 2014). Oleh karena itu, sekolah menjadi kekuatan terbesar dalam upaya mewujudkan ESD utamanya di Sekolah Dasar (Prastowo et al., 2014). Maka dari itu, penanaman nilai-nilai berkelanjutan sangat cocok terlebih dahulu di implementasikan di sekolah dasar. Pengimplementasian kurikulum 2013 di sekolah dasar dengan berbasis ESD menurut UNESCO ditandai dengan pengintegrasian 3 pilar pembangunan yaitu lingkungan, ekonomi dan sosial-budaya dalam proses pembelajaran (Mochtar et al., 2014). Di Indonesia sendiri sebenarnya pengimplementasian ESD itu bukanlah hal yang baru. Namun penyelenggaraanya masih belum terlaksana secara optimal (Shantini, 2016). Maka dari itu, sebagai pelaksana pendidikan guru harus menjalankan perannya untuk turut serta mewujudkan pengimplementasian ESD di Indonesia yaitu dengan melakukan Inovasi dalam pembelajaran yang dapat dilakukan dengan mengembangkan model, media ataupun perangkat pembelajaran (Kurniawati, 2018). Oleh karena itu, diperlukan perangkat pembelajaran yang di dalamnya mengandung nilai-nilai ESD salah satunya pengembangan bahan ajar berupa modul pembelajaran. Dengan penggunaan modul berbasis ESD ini diharapkan dapat membantu mewujudkan ESD di Indonesia.

Namun, saat ini sumber-sumber yang sesuai sebagai materi pendidikan yang sejalan dengan tema dan nilai keberlanjutan masih langka (Mohammadnia \& Moghadam, 2019). Selain itu, penggunaan modul dalam pembelajaran pun masih sangat kurang, hal tersebut didasarkan dari hasil penyebaran angket berdasarkan analisis kebutuhan yang dilakukan oleh (Rahman et al., 2019) didapatkan bahwa bahan ajar yang digunakan yaitu $100 \%$ buku paket, 66,7\% LKS, dan 33,3\% modul pembelajaran. Hal tersebut dapat membuktikan bahwa penggunaan modul dalam pembelajaran masih sangat kurang.

Selain itu, dengan adanya perkembangan Ilmu Pengetahuan dan Teknologi (IPTEK) juga turut merubah pandangan pembangunan pendidikan utamanya dalam proses pendidikan salah satunya adalah bahan ajar. Inovasi dari pengembangan bahan ajar diantaranya adalah modul yang dikemas secara elektronik (e-modul). 
1823 Analisis Kebutuhan Pengembangan Elektronik Modul Berbasis Education For Sustainable Development untuk Siswa di Sekolah Dasar - Nurul Hadi Yanti, Ghullam Hamdu

DOI: https://doi.org/10.31004/edukatif.v3i4.632

Sebelumnya memang telah dilaksanakan penelitian yang dilakukan juga oleh (Purwoko et al., 2020; Utami \& Yuwaningsih, 2020; Vitrianingsih et al., 2021) yang membahas mengenai analisis kebutuhan pengembangan elektronik modul hanya saja ditujukan untuk siswa SMP bukan SD dan tidak berbasis ESD. Selain itu, terdapat juga penelitian mengenai analisis kebutuhan pengembangan modul untuk siswa Sekolah Dasar yang dilakukan oleh (Deviana, 2018), namun dalam penelitian tersebut analisis kebutuhan pengembangan modulnya tidak dalam bentuk elektronik dan berbasis kearifan lokal. Oleh karena itu, penelitian untuk menganalisis kebutuhan pengembangan elektronik modul berbasis Education For Sustainable Development untuk siswa kelas V Sekolah Dasar dirasa perlu untuk dilakukan.

Analisis kebutuhan pengembangan elektronik modul pembelajaran berbasis ESD ini meliputi analisis kurikulum, analisis siswa, serta analisis kondisi lapangan. Berbagai analisis dilakukan untuk mengetahui kebutuhan perlu dikembangannya modul pembelajaran berbasis ESD yang menyeluruh. Analisis kebutuhan yang menyeluruh dan akurat diharapkan dapat dikembangkan modul pembelajaran berbasis ESD yang sesuai dengan kebutuhan lapangan.

Tujuan dari penelitian ini adalah untuk menganalisis kebutuhan pengembangan e-modul berbasis ESD di kelas $\mathrm{V}$ sekolah dasar. Hasil dari penelitian ini diharapkan dapat memberikan informasi awal mengenai pengembangan e-modul yang dapat digunakan sebagai bahan ajar pendukung proses pembelajaran.

\section{METODE PENELITIAN}

Penelitian ini menggunakan metode kualitatif dengan metode deskriptif. Penelitian ini dilakukan selama kurang lebih 1 bulan dari tanggal 23 Maret 2021 sampai 24 April 2021 yang melibatkan beberapa subjek, adapun pemilihan subjeknya didahului dengan analisis masalah dengan mengidentifikasi karakteristik Guru dan siswa Sekolah Dasar terhadap beberapa SD di Kabupaten dan kota Tasikmalaya. Maka dipilihlah 6 orang guru kelas V dan 7 Orang Siswa kelas V dari empat sekolah yang berbeda, satu sekolah berada di Kota Tasikmalaya dan 3 sekolah berada di Kabupaten Tasikmakaya.

Adapun kriteria guru yang dijadikan informan adalah sebagai berikut :1) Pengalaman mengajar minimal 2 tahun, 2) Memiliki kualifikasi profesi yang memadai antara lain: pendidikan terakhir minimal S1, dan khusus untuk PNS mempunyai golongan II A atau II B, 3) Memiliki kompetensi keilmuan sesuai materi yang diampunya, 4) Sehat jasmani dan rohani, 5) Melek teknologi.

Sumber data dalam penelitian ini diperoleh dari sumber data primer dan sumber data sekunder. Sumber data primer diperoleh dari para informan yang dianggap paling mengetahui secara rinci dan jelas mengenai fokus penelitian. Sedangkan sumber data sekunder diperoleh melalui studi observasi terhadap pelaksanaan pembelajaran dan dokumentasi yang meliputi pemetaan KD, dokumen bahan ajar termasuk modul yang digunakan serta data pendukung lainnya.

Adapun prosedur penelitian yang dilakukan peneliti akan diilustrasikan pada Gambar 1 berikut :

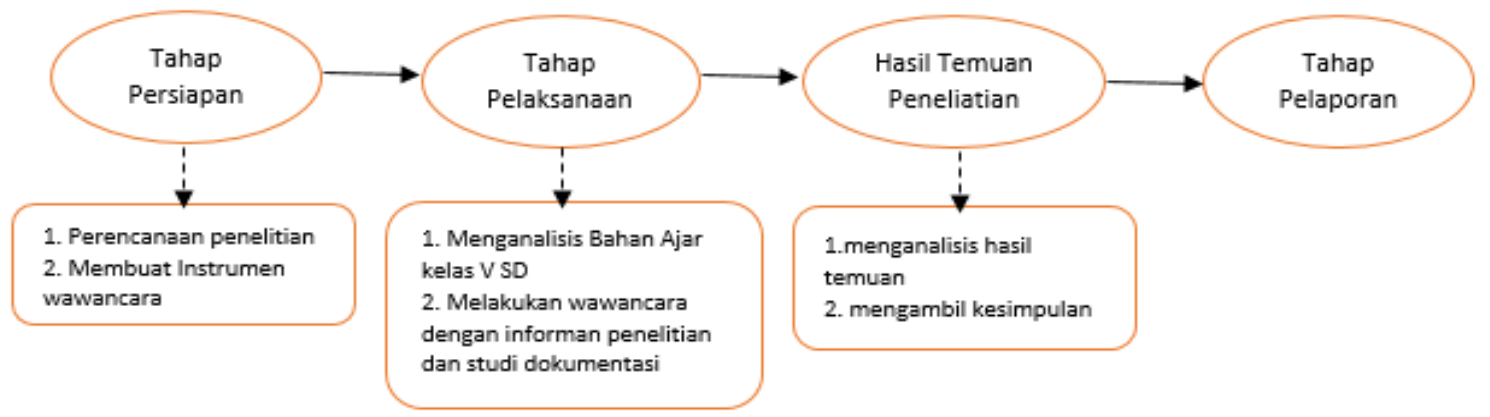

Gambar 1. Prosedur Penelitian 
1824 Analisis Kebutuhan Pengembangan Elektronik Modul Berbasis Education For Sustainable Development untuk Siswa di Sekolah Dasar - Nurul Hadi Yanti, Ghullam Hamdu

DOI: https://doi.org/10.31004/edukatif.v3i4.632

Peneliti menggunakan dua teknik untuk memperoleh data di lapangan, yaitu: teknik wawancara dan studi dokumentasi. Untuk analisis data dalam penelitian ini mengacu pada analisis kualitatif yang dinyatakan oleh Miles and Huberman. Adapun tahapan yang digunakan dalam melakukan analisa data yaitu: data reduction, data display dan conclusion and verifying (Miles \& Hubberman, 1992).

\title{
HASIL DAN PEMBAHASAN PENELITIAN
}

Berdasarkan analisis terhadap beberapa aspek, diperoleh hasil sebagai berikut :

\section{Analisis Kurikulum}

Peneliti melakukan analisis terhadap jaringan Kompetensi Dasar (KD) untuk kelas V yang relevan dengan 3 pilar Education for Sustainable Development (ESD) yaitu pilar ekonomi, sosial dan lingkungan. Peneliti mengidentifikasi KD pada kelas V yang mengandung tiga pilar ESD tersebut. Analisis ini didasarkan pada tema-tema yang tercantum dalam ESD yang sudah ditetapkan UNESCO. Adapun KD yang bermuatan pilar Lingkungan terdapat satu pasang yang disajikan dalam Tabel 1.

Tabel 1. Pasangan Kompetensi Dasar pilar Lingkungan

\begin{tabular}{|c|c|}
\hline KD Pengetahuan & KD Keterampilan \\
\hline $\begin{array}{l}\text { 3.5 Menganalisis hubungan antar komponen } \\
\text { ekosistem dan jaring-jaring makanan di } \\
\text { lingkungan sekitar. }\end{array}$ & $\begin{array}{l}\text { 4.5. membuat karya tentang } \\
\text { jaring-jaring makanan dalam suatu } \\
\text { ekosistem. }\end{array}$ \\
\hline
\end{tabular}

Sementara itu yang bermuatan sosial dan Ekonomi terdapat dua pasang KD disajikan dalam Tabel 2.

Tabel 2. Pasangan Kompetensi Dasar pilar Ekonomi dan Sosial

\begin{tabular}{lll}
\hline \multicolumn{2}{c}{ KD Pengetahuan } & \multicolumn{2}{c}{ KD Keterampilan } \\
\hline 3.1 mengidentifikasi karakteristik geografis & 4.1 menyajikan hasil identifikasi \\
Indonesia sebagai negara Maritim dan agraris & karakteristik geografis Indonesia sebagai \\
serta pengaruhna terhadap kehidupan ekonomi, & negara Maritim dan agraris serta \\
sosial, budaya, komunikasi serta transportasi. & $\begin{array}{l}\text { pengaruhna terhadap kehidupan } \\
\text { ekonomi, sosial, budaya, komunikasi }\end{array}$ \\
& serta transportasi.
\end{tabular}

3.2 menganalisis bentuk-bentuk interaksi 4.2 menyajikan hasil analisis bentukmanusia dengan lingkungannya dan pengaruhnya bentuk interaksi manusia dengan terhadap pembangunan sosial, ekonomi, budaya lingkungannya dan pengaruhnya dan ekonomi masyarakat Indonesia. terhadap pembangunan.

\begin{abstract}
Hasil tersebut menunjukkan bahwa di kelas V sudah terdapat KD yang bermuatan 3 pilar ESD, hanya saja dalam pelaksanaannya belum dilakukan secara bersamaan untuk satu kali pembelajaran. Pengimpelementasiannya masih terpisah antara 3 pilar tersebut. Sesuai dengan penelitian yang dilaksanakan oleh (Listiawati, 2013) dan (Supriatna et al., 2018) yang menyatakan bahwa pengimplementasian ESD di Indonesia masih terpokus pada aspek lingkungannya saja dan belum mengintegrasikan 2 pilar lainnya yaitu pilar sosial dan ekonomi.
\end{abstract}

\section{Analisis Bahan Ajar yang digunakan}

Berdasarkan hasil analisis, Bahan ajar yang digunakan oleh sebagian besar Sekolah Dasar di kabupaten maupun di kota Tasikmalaya adalah buku ajar tematatik 2013 terbitan kemendikbud. Hasil analisis terhadap buku tersebut di dapatkan bahwa buku tersebut memuat sedikit materi namun tuntutan mengisi latihan soal untuk anak sangat luas, sehingga anak kurang mampu mengembangkan pengetahuannya sendiri. Sejalan 
1825 Analisis Kebutuhan Pengembangan Elektronik Modul Berbasis Education For Sustainable Development untuk Siswa di Sekolah Dasar - Nurul Hadi Yanti, Ghullam Hamdu

DOI: https://doi.org/10.31004/edukatif.v3i4.632

dengan itu, penelitian yang dilakukan oleh (Indrawini et al., 2017) menyatakan bahwa penerapan bahan ajar pokok terbitan kemendikbud memiliki kekurangan dalam aspek kecakupan materi dan latihan soalnya.

Selain itu, terdapat beberapa materi yang disajikan secara terpisah kelanjutannya, sehingga akan membuat anak kebingungan materi ini merupakan kelanjutan dari mana. Buku tersebut pun terdapat materi yang diulang-ulang. Sehingga menurut (Rosilia et al., 2020) sebelum melaksanakan pembelajaran, guru diharapkan mempersiapkan dahulu bahan ajar yang sesuai dengan kebutuhan dan karakter siswa, sehingga bahan ajar tersebut dapat difungsikan secara maksimal untuk membantu siswa memahami materi yang diajarkan.

\section{Analisis Siswa}

Hasil wawancara kepada 7 orang siswa kelas V dari empat sekolah yang berbeda di kabupaten dan kota Tasikmalaya menunjukkan bahwa siswa menginginkan sebuah modul untuk mereka belajar di rumah dengan tampilan bukunya ingin yang menarik dan banyak gambar supaya mereka tidak bosan. Hal ini sesuai dengan pendapat (Majid, 2014) yang menyatakan bahwa "Pada usia ini anak berada pada tahap operasional konkret (7-11 tahun) yang ditandai oleh kemampuan berpikir konkret dan mendalam". Pembelajaran di sekolah dasar sepatutnya dapat mengembangkan minat dan bakat, menyenangkan, dan menarik, sehingga pembelajaran tidak jenuh dan tidak membosankan. Hal tersebut disebabkan karena siswa mempunyai tingkat kreativitas yang berbeda-beda. Hal tersebut sesuai dengan pendapat (Sepriana et al., 2019) yang menyatakan bahwa siswa itu ada yang sudah mempunyai tingkat kreativitas yang tinggi namun ada juga yang masih rendah, sehingga kemampuan untuk dapat memecahkan masalah juga berbeda.

\section{Hasil wawancara kepada guru kelas V}

Peneliti melakukan wawancara kepada 6 orang guru kelas V dari 4 Sekolah Dasar Negeri yang berbeda. 4 orang guru berada di Kabupaten Tasikmalaya dan 2 orang guru berada di kota Tasikmalaya. Wawancara tersebut terbagi ke dalam empat pembahasan diantaranya mengenai: penggunaan bahan ajar, penggunaan modul untuk pembelajaran di luar kelas (rumah), pengintegrasian pendekatan pendidikan untuk pembangunan berkelanjutan (ESD) dalam pembelajaran kurikulum 2013 dan kebutuhan pengembangan elektronik modul berbasis ESD.

Berdasarkan hasil pengumpulan data melalui wawancara yang dilakukan peneliti didapatkan bahwa dalam penggunaan bahan ajar semua guru menyatakan bahwa itu merupakan hal yang penting karena sebagai acuan dalam penyampaian materi kepada siswa dan membantu proses pembelajaran. Hal tersebut dikuatkan juga oleh (Aisyah et al., 2020) bila tanpa bahan ajar, tampaknya guru akan mengalami kesulitan dalam mencapai tujuan pembelajaran. Oleh karenanya, guru harus selalu menyiapkan bahan ajar selama pelaksanaan proses pembelajaran.

Dalam penggunaan bahan ajar tersebut sebagian besar sekolah dasar negeri baik di kabupaten maupun di kota Tasikmalaya hanya mengunakan buku ajar tematik kurikulum 2013 terbitan kemendikbud saja. Para guru menuturkan bahwa bahan ajar yang digunakan saat ini masih memiliki kekurangan seperti terdapat beberapa materi yang diulang-ulang sehingga membuat anak bosan dan kurang bersemangat dalam belajar sehingga bahan ajar tersebut belum memenuhi kebutuhan peserta didik. Hal ini sejalan dengan penelitian yang dilakukan (Rosilia et al., 2020) yang menyatakan bahwa buku siswa memiliki kekurangan dalam cakupan materi dan latihan soal. Oleh karena itu, mengingat bahan ajar yang digunakan saat ini berisi materi yang kurang luas jadi dibutuhkan modul untuk mendalami materi dan pemberian tugas mandiri. Banyak kebaikan yang diakibatkan dari penggunaan modul dalam pembelajaran salah satunya adalah yang diungkapkan (Nurnisa et al., 2019) bahwa hasil penelitiannya menunjukkan Rata-rata kelompok yang diajar menggunakan modul yaitu 66.20 lebih besar dibandingkan dengan sebelum dengan modul yakni 37.00. Data tersebut menunjukkan bahwa adanya peningkatan hasil belajar dari aspek kognitif antar peserta didik yang telah menggunakan media pembelajaran modul dengan hasil belajar peserta didik yang sebelum menggunakan modul tersebut. 
Selanjutnya dikarenakan sekarang penggunaan teknologi sudah merambat luas, yang mengharuskan sekolah secara online mau tidak mau semua pihak pengelola pendidikan harus ikut serta beradaptasi. Dengan hadirnya elektronik modul atau modul yang dapat diakses siswa secara digital sangat disambut dengan baik oleh semua guru karena guru juga bertanggung jawab untuk menyampaikan kebutuhan perkembangan IPTEK kepada murid. Menurut (Sanjaya, 2012), Elektronik Modul merupakan suatu versi buku yang dapat dibuka secara elektronis melalui komputer/handphone. Sebagai salah satu sarana pendukung pembelajaran siswa secara mandiri, elektronik modul tetap harus memenuhi syarat buku ajar sesuai ketentuan Badan Standar Nasional Pendidikan (BSNP, 2010) meliputi tiga kriteria, yaitu kriteria kelayakan isi modul, kebahasaan dan penyajian modul. Penggunaan e-modul menjadikan siswa tertarik dalam proses belajar, sebab dapat diakses kapanpun dan kondisi dimanapun didukung dengan alat yang memadai, dan tidak menyulitkan siswa (Elvarita et al., 2020).

Menurut (Sanjaya, 2012) penggunaan e-modul menjadikan siswa tertarik dalam proses belajar, sebab dapat diakses kapanpun dan kondisi dimanapun didukung dengan alat yang memadai, dan tidak menyulitkan siswa (Elvarita et al., 2020). Modul elektronik juga dapat dilengkapi dengan animasi dan gambar yang bergerak sehingga terciptalah pengalaman belajar yang baru dan tidak membosankan, dan tes formatif yang dilengkapi dengan pengiriman umpan balik secara otomatis sehingga siswa dapat mengetahui hasil evaluasi yang dikerjakannya (Jonias, 2014; Zulkarnain et al., 2015). Modul pembelajaran elektronik memiliki karakteristik yang sama dengan modul cetak hanya saja yang menjadi perbedaan yaitu elekronik modul disajikan dalam bentuk digital. Hal tersebut sesuai dengan yang diungkapkan (Fausih \& Danang, 2015) bahwa karakteristik elektronik modul diantaranya self instructional yang artinya hanya mencakup satu materi pembelajaran saja sehingga siswa benar fokus pada materi yang sedang diajarkan. Self contained yaitu keseluruhan komponen materi tercantum secara rinci dalam modul. Stand alone artinya modul dapat digunakan sendiri jadi tidak bergantung dengan media lain. Adaptif karena pengembangan e-modul sesuai dengan karakter siswa dan User frendly artinya cocok dengan penggunanya.

Selain itu, dalam pembelajaran kurikulum 2013 khususnya di kelas V semua guru sepakat bahwa sudah terdapat materi mengenai lingkungan, sosial dan ekonomi, walaupun dalam penerapannya masih terpisah belum terdapat dalam satu kali pembelajaran (Listiawati, 2013). Hal tersebut menunjukkan bahwa dalam kurikulum 2013 sudah termuat pilar-pilar Education for Sustainable Development (ESD), namun semua guru yang menjadi informan belum mengetahui hal tersebut. Mengingat pendekatan pembelajaran berbasis ESD harus diintegrasikan dalam semua kurikulum pendidikan formal disemua jenjang pendidikan, ESD menyangkut inti pengajaran dan pembelajaran dan tidak boleh dianggap sebagai tambahan pada kurikulum yang ada (Putu Wulandari Tristananda, 2018).

Kemdiknas (2010) mengemukakan bahwa konsep ESD sebagai pendidikan yang bermakna, berfungsi dan bertujuan untuk 1) pendidikan yang mampu memenuhi kebutuhan hidup manusia untuk masa sekarang tanpa mengesampingkan generasi masa depan untuk memenuhi kebutuhan hidup mereka, 2) meningkatkan mutu hidup manusia dengan tetap hidup di dalam daya dukung ekosistem, dan 3) menguntungkan bagi semua makhluk di bumi (manusia dan ekosistem) pada masa kini maupun di masa yang akan datang. ESD juga berkontribusi untuk akusisi dan praktek pengetahuan, nilai-nilai, dan keterampilan yang memastikan keseimbangan antara ekonomi, sosial dan aspek lingkungan dari pembangunan berkelanjutan sebagai upaya kemajuan dalam hidup baik individu maupun masyarakat (UNESCO-Beirut, 2008).

Salah satu cara untuk mengintegrasikan ESD dalam pembelajaran adalah dengan memasukan konsep pilar-pilar ESD ke dalam materi bahan ajar seperti modul yang dijadikan pedoman siswa saat belajar secara mandiri.

\section{KESIMPULAN}


1827 Analisis Kebutuhan Pengembangan Elektronik Modul Berbasis Education For Sustainable Development untuk Siswa di Sekolah Dasar - Nurul Hadi Yanti, Ghullam Hamdu

DOI: https://doi.org/10.31004/edukatif.v3i4.632

Berdasarkan hasil penelitian yang dilakukan dapat disimpulkan bahwa penggunaan bahan ajar di kelas V Sekolah Dasar masih belum memenuhi kebutuhan peserta didik, sehigga guru dan peserta didik membutuhkan bahan ajar untuk peserta didik belajar secara mandiri berupa E-Modul berbasis Education for Sustainable Development (ESD) untuk siswa kelas V Sekolah Dasar. Dalam penelitian ini peneliti hanya menganalisa kebutuhan E-Modul berbasis ESD sebagai bahan ajar tambahan dalam pembelajaran. Penelitian ini membutuhkan penelitian lanjutan untuk mengembangkan elektronik modul berbasis Education for Sustainable Development (ESD) untuk siswa kelas V Sekolah Dasar.

\section{UCAPAN TERIMA KASIH}

Ucapan terima kasih penulis haturkan kepada seluruh pihak yang terlibat dalam penelitian ini utamanya kepada setiap sekolah yang digunakan untuk pengambilan data untuk penelitian ini.

\section{DAFTAR PUSTAKA}

Aisyah, S., Noviyanti, E., \& Triyanto. (2020). Bahan Ajar Sebagai Bagian Dalam Kajian Problematika Pembelajaran Bahasa Indonesia. Jurnal Salaka, 2(1), 62-65. http://garuda.ristekbrin.go.id/documents/detail/1653809

BSNP. (2010). Standar Penulisan Buku Ajar. http://library1.nida.ac.th/termpaper6/sd/2554/19755.pdf

Deviana, T. (2018). Analisis Kebutuhan Pengembangan Modul Pembelajaran Berbasis Kearifan Lokal Kabupaten Tulungagung Untuk Kelas V Sd Tema Bangga Sebagai Bangsa Indonesia. Jurnal Pemikiran Dan Pengembangan Sekolah Dasar (JP2SD), 6(1), 47. https://doi.org/10.22219/jp2sd.v6i1.5902

Dolong, H. M. J. (2016). Teknik analisis dalam komponen pembelajaran. Jurnal UIN Alauddin, 5(2), 293300.

Elvarita, A., Iriani, T., \& Handoyo, S. S. (2020). PENGEMBANGAN BAHAN AJAR MEKANIKA TANAH BERBASIS E-MODUL PADA PROGRAM STUDI PENDIDIKAN TEKNIK BANGUNAN, UNIVERSITAS NEGERI JAKARTA. Jurnal Pendidikan Teknik Sipil (JPenSil), 9(1), 1-7.

Fausih, M., \& Danang, T. (2015). Pengembangan Media E-Modul Mata Pelajaran Produktif Pokok Bahasan "Instalasi Jaringan Lan (Local Area Network)" Untuk Siswa Kelas Xi Jurusan Teknik Komputer Jaringan Di Smk Nengeri 1 Labang Bangkalan Madura. Jurnal UNESA, 01(01), 1-9. https://jurnalmahasiswa.unesa.ac.id/index.php/jmtp/article/view/10375

Indrawini, T., Amirudin, A., \& Widiati, U. (2017). Pentingnya Pengembangan Bahan Ajar Tematik untuk Mencapai Pembelajaran Bermakna bagi Siswa Sekolah Dasar. In Prosiding Seminar Nasional Mahasiswa Kerjasama Direktorat Jenderal Guru Dan Tenaga Kependidikan Kemendikbud 2016., 1-7.

Jonias, H. (2014). PENGEMBANGAN MEDIA PEMBELAJARAN E-MODULE TERHADAP PRESTASI BELAJAR SISWA DALAM MATA PELAJARAN MUATAN LOKAL ELEKTRONIKA DI SMPN 6 SURABAYA Hendri Jonias. Jurnal Pendidikan Teknik Elektro, 03(03), 645-649.

Kemdiknas. (2009). Peraturan Mentri Pendidikan Nasional No 63 tentang sistem Penjaminan Mutu Pendidikan. Kemdiknas.

Kemdiknas. (2010). Model Pendidikan untuk Pembangunan Berkelanjutan (Education for Sustainable Development / ESD) melalui kegiatan Intrakulikuler. Pusat Penelitian Kebijakan, Balitbang Kemdiknas.

Kurniawati, N. (2018). Pengembangan Media Pembelajaran Lembar Kerja Peseta Didik (LKPD) Berbantuan Geogebra pada Materi Turunan. In http://repository.radenintan.ac.id/: Vol. (Issue 9). www.journal.uta45jakarta.ac.id

Listiawati, N. (2013). Pelaksanaan Pendidikan untuk Pembangunan Berkelanjutan oleh Beberapa Lembaga. 
1828 Analisis Kebutuhan Pengembangan Elektronik Modul Berbasis Education For Sustainable Development untuk Siswa di Sekolah Dasar - Nurul Hadi Yanti, Ghullam Hamdu

DOI: https://doi.org/10.31004/edukatif.v3i4.632

Jurnal Pendidikan Dan Kebudayaan, 19(3), 430. https://doi.org/10.24832/jpnk.v19i3.302

Majid, A. (2010). Manajemen Pendidikan Islam.

Majid, A. (2014). Pembelajaran Tematik Terpadu. PT.Remaja Rosdakarya.

Miles, M. B., \& Hubberman, A. . (1992). Analisis Data Kualitatif: Buku Sumber Tentang Metode-metode Baru Terjemahan Tjetjep Rohendi Rohidi. Universitas Indonesia Press.

Mochtar, N. E., Gasim, H., Hendarman, N. I., Wijiasih, A., Suryana, C., Restuningsih, K., \& Tartila, S. L. (2014). Pendidikan untuk Pembangunan Berkelanjutan (Education for Sustainable Development) di Indonesia. In Komisi Nasional Indoneisa untuk UNESCO Kementrian Pendidikan dan Kebudayaan (Issue 9).

Mohammadnia, Z., \& Moghadam, F. D. (2019). Textbooks as resources for education for sustainable development: A content analysis. Journal of Teacher Education for Sustainability, 21(1), 103-114. https://doi.org/10.2478/jtes-2019-0008

Nurnisa, Ismail, I., \& Ismail, W. (2019). Pengembangan Modul Biologi Berbasis Pendekatan Contextual Teaching and Learning ( Ctl ) Di Smpn 3. Al Ahya, 1(1), 70-82.

PP. (2005). Peraturan Pemerintah Nomor 19 Pasal 20 tentang Perencanaan Pembelajaran. Pemerintahan RI.

Prastowo, A., Studi, P., Guru, P., \& Ibtidaiyah, M. (2014). Kebutuhan Psikologis Dengan Tematik. Jurnal Pendidikan Sekolah Dasar, 1, 1-13.

Purwoko, R. Y., Nugraheni, P., \& Nadhilah, S. (2020). Analisis Kebutuhan Pengembangan E -Modul Berbasis Etnomatematika Produk Budaya Jawa Tengah. Jurnal Penelitian Matematika Dan Pendidikan Matematika, 5(1), 1-8.

Putu Wulandari Tristananda. (2018). Membumikan Education for Sustainable Development (ESD) di Indonesia dalam menghadapi isu - isu global. Jurnal Agama Dan Budaya, 2(2), 42-49.

Rahman, A., Heryanti, L. M., \& Ekanara, B. (2019). Pengembangan Modul Berbasis Education for Sustainable Development pada Konsep Ekologi untuk Siswa Kelas X SMA. Jurnal Eksakta Pendidikan (Jep), 3(1), 1. https://doi.org/10.24036/jep/vol3-iss1/273

Rosilia, P., Yuniawatika, Y., \& Murdiyah, S. (2020). Analisis kebutuhan bahan ajar siswa di kelas III SDN Bendogerit 2 Kota Blitar. Premiere Educandum: Jurnal Pendidikan Dasar Dan Pembelajaran, 10(2), 125. https://doi.org/10.25273/pe.v10i2.6306

Sanjaya, I. G. M. (2012). PENGEMBANGAN E-BOOK INTERAKTIF PADA MATERI KIMIA UNSUR UNTUK KELAS XII. Unesa Journal of Chemical Education, 1(2), 7-10.

Sepriana, R., Sefriani, R., Wijaya, I., \& Lestari, P. (2019). Pengujian Validitas Modul Interaktif Simulasi Dan Komunukasi Digital Berbasis Macromedia Director Mx. Edukatif: Jurnal Ilmu Pendidikan, 1(3), 120 126. https://doi.org/10.31004/edukatif.v1i3.25

Shantini, Y. (2016). PENYELENGGARAAN EfSD DALAM JALUR PENDIDIKAN DI INDONESIA. PEDAGOGIA Jurnal Ilmu Pendidikan, 13(1), 136. https://doi.org/10.17509/pedagogia.v13i1.3385

Supriatna, N., Romadona, N. F., Saputri, A. E., Darmayanti, M., \& Indonesia, U. P. (2018). Implementasi Education for Sustainable Development ( Esd ) Melalui Ecopedagogy Dalam Pembelajaran tematik di Sekolah Dasar. Primaria Educationem Journal, $1(2), \quad 80-86$. http://journal.unla.ac.id/index.php/pej/article/view/1077/748

UNESCO-Beirut. (2008). Regional Guiding Framework of ESD for the Arab Region.

Utami, W. T., \& Yuwaningsih, D. A. (2020). ANALISIS KEBUTUHAN PENGEMBANGAN E-MODUL PADA POKOK BAHASAN TURUNAN MENGGUNAKAN KVISOFT FLIPBOOK MAKER PRO UNTUK SISWA SMA KELAS XI. Prosiding Seminar Nasional Konferensi Ilmiah Pendidikan, 1(1), $158-160$. 
1829 Analisis Kebutuhan Pengembangan Elektronik Modul Berbasis Education For Sustainable Development untuk Siswa di Sekolah Dasar - Nurul Hadi Yanti, Ghullam Hamdu DOI: https://doi.org/10.31004/edukatif.v3i4.632

Vitrianingsih, D., Aulianingsih, I., \& Yuliani, H. (2021). Analisis Kebutuhan Pengembangan Modul Elektronik (E-Module) IPA Terintegrasi Islam. Jurnal Ilmiah Pendidikan Fisika, 5(1), 27. https://doi.org/10.20527/jipf.v5i1.2525

Zulkarnain, A., Kadaritna, N., \& Tania, L. (2015). Pengembangan E-Modul Teori Atom Mekanika Kuantumberbasis Web Dengan Pendekatan Saintifik. Jurnal Pendidikan Dan Pembelajaran Kimia, $4(1), 222-235$. 